\title{
'MAPAGI' video game upgraded breakfast attitude among urban elementary school children in West Jakarta, Indonesia
}

\author{
Dudung Angkasa*, Riri Amanda Pratiwi \& Idrus Jus'at \\ Department of Nutrition, Faculty of Health Sciences, Universitas Esa Unggul, Jakarta, \\ Indonesia
}

\begin{abstract}
Introduction: Skipping breakfast may contribute to poor academic and nutritional status among school children. The current study aimed to determine the effect of the 'MAPAGI' (Makan Pagi Bergizi) interactive video game on elementary student's breakfast knowledge and attitude. Methods: This was a quasi-experimental equivalent group study with a pre-post test control group design. In total, 228 students aged 9-11 years were drawn by proportional stratified random sampling from two urban schools and were distributed equally into intervention (IG) and control groups (CG). Both groups were administered with similar printed media for 10-15 minutes. Video game was delivered only to IG for two consecutive days, 30 minutes each day. Pre-test (PTO) was performed a day before leaflet administration, while post-test was performed twice - after leaflet administration (post-test 1/ PT1) and a week after the last video game (post-test 2/PT2). Paired, independent $t$-test and analysis of covariance (ANCOVA) were employed to answer the research questions. Results: The mean changes (PT1-PT0 and PT2-PT0) in knowledge score for IG $(4.82 \pm 2.53$ and $3.25 \pm 2.47)$ significantly differed compared to CG $(1.75 \pm 2.66$ and 1.25 \pm 2.69$)$. The mean changes in attitude score for IG $(7.16 \pm 7.17$ and $7.34 \pm 7.11)$ also significantly differed compared to CG $(2.83 \pm 6.58$ and $2.64 \pm 6.90)$. After adjustment for potential confounding factors, there was still a significantly greater score in children's knowledge and attitude after a week's administration of MAPAGI video game in IG. Conclusion: 'MAPAGI' improved school children's knowledge and attitude, which may lead to the good behaviour of having breakfast.
\end{abstract}

Keywords: Breakfast, nutrition education, knowledge, attitude, video game

\section{INTRODUCTION}

School-age children who skip breakfast will tend to have poor academic performance (Adolphus, Lawton \& Dye, 2013; Kawafha, 2013; Smith et al., 2017) and nutritional status (Garg, Rajesh \& Kumar, 2014), as well as a higher risk of metabolic syndrome in adulthood (Shafiee et al., 2013). Ironically, in Indonesia, $20-40 \%$ of elementary school children skip their breakfast meals. Lack of knowledge and wrong assumption of breakfast are still the main reasons for skipping breakfast (Kigaru et al., 2015). Studies showed that children with a lack of knowledge on breakfast ranged from 30.0-47.8\% (Irnani \& Sinaga, 2017), while among those with good knowledge, there were still some who assumed that junk food can be a

\footnotetext{
*Corresponding author: Dudung Angkasa

Department of Nutrition, Faculty of Health Sciences, Universitas Esa Unggul, Jakarta, Indonesia

Tel: +6221 5674223; E-mail: dudung.angkasa@esaunggul.ac.id

doi: https://doi.org/10.31246/mjn-2019-0127
} 
meal for a healthy breakfast (Garg et al., 2014; Kigaru et al., 2015). A recent study reported (Permaesih \& Rosmalina, $2017)$ that $77.5 \%$ of school-age children (6-12 years old) had breakfast but in a low variety of food groups. Among those who had breakfast, $72.3 \%$ consumed only the cereal food group, while $49.6 \%$ consumed three food groups that composed of cereal, animal protein and oil (fried).

Nutrition and health education is one of the best interventions to encourage healthy eating habits (CDC, 2012). Moreover, a systematic review reported that nutrition-health education is proven to improve knowledge, attitude and eating habit, as well as nutritional status of children and adolescents (Silveira et al., 2011).

Particularly in Indonesia, several studies had been conducted to improve the eating habits of children by using media such as printed materials (Angkasa et al., 2017; Nuryanto et al., 2014), animated media (Briawan, Ekayanti \& Koerniawati, 2013), puppet toy show (Briawan et al., 2013), and roleplay (Maduretno, Wirawan \& Setijowati, 2015). Several channels such as attached media (self-reading) (Angkasa et al., 2017; Nuryanto et al., 2014) and the involvement of teachers and parents (Eliassen, 2011; Nuryanto et al., 2014) were also used to deliver nutrition and health education. These studies found significant increment in knowledge (Angkasa et al., 2017; Nuryanto et al., 2014), attitude (Briawan et al., 2013; Maduretno et al., 2015; Nuryanto et al., 2014) and eating habits (Briawan et al., 2013; Maduretno et al., 2015) scores after administering either media alone or both media with the involvement of teachers and parents. However, these studies did not control for confounding factors such as children's sex and parental characteristics (Angkasa et al., 2017;
Briawan et al., 2013; Maduretno et al., 2015; Nuryanto et al., 2014). Moreover, the nutrition education methods and media depended on the attendance of the researchers. Printed media, animated media such as PowerPoint, or role-play and puppet show are dependent on the instruction and explanation from the researchers. Thus, the development of media that can be self-explained and self-instructed, as well as can be played in individual or team mode are needed.

Video game is one of the alternative media that can fulfil these requirements. 'Makan Pagi Bergizi' (MAPAGI) or 'Nutritious Breakfast Meal' is one of such examples that had already been developed from our previous study (Pratiwi, 2015). The current study aimed to examine the effect of MAPAGI games as one of the teaching media in modifying the knowledge and attitude of school children towards nutritious breakfast habits. This game can be incorporated in elementary school courses, especially the ones related to nutrition and health such as natural science (biology and environment, ilmu pengetahuan alam), sport or basic computer science for children. Eventually, this study also tried to find the adjusted score for the group that was assigned to MAPAGI games against the group which was not assigned to the intervention.

\section{MATERIALS AND METHODS}

\section{Study design}

This was a quasi-experimental study conducted in two urban schools in West Jakarta in January 2017. The schools were chosen purposively, focusing particularly on those which have computer facilities.

\section{Participants and recruitment}

Participants were children aged 9-12 years old who were formally registered 
in the targeted schools, fulfilled the inclusion criteria and were permitted by their parents (written informed consent) to join the study. Inclusion criteria were a) able to operate a personal computer/ laptop, b) present in all observation stages, and c) able to communicate normally. In total, 228 students were involved in the study, which comprised of 114 from one school in the control arm and 114 from another school in the intervention arm. The sample size was determined by two independent mean differences, with $\alpha=0.05$, power $=0.95$ and effect size 0.481 from a previous study (Pratiwi, 2015). Samples were drawn proportionally by stratified random sampling.

\section{Data collection}

The primary data were collected by twelve trained enumerators using a structured and previously pre-tested questionnaire. Besides student's knowledge and attitude on breakfast, the questionnaire also inquired on parental education and working status, which may be associated with children's breakfast behaviours. The two groups in this study received nutrition education using leaflets and posters, while the intervention group was given an additional video game media. The day before nutrition education, the intervention and control groups were given a pre-test (PTO). The next day, both groups received nutrition education using IEC (information, education and communication) media with the same materials for a duration of 10 to 15 minutes. In the intervention group, video game was provided on two consecutive days and was played for 30 minutes each day. Post-test 1 (PT1) was done 30 minutes after the intervention was given, while post-test 2 (PT2) was done 1 week later (Figure 1). The main purpose of PT2 was to examine the short versus long-term memory or the amount of information that were still remembered by the children.

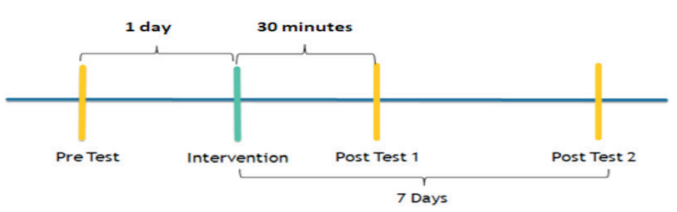

Figure 1. The flow of the study

\section{MAPAGI video game}

This game is an internet-based video game that needs an internet connection and can be self-administered. Detailed description of the game is provided in our previous study (Pratiwi, 2015). The game consisted of 10 levels. Levels 1 and 5 contained a challenge of choosing the right picture. Levels 2 and 9 contained 'guessing words'. In Levels 3 and 7, children were directed to fill the My Plate (the recommended portion of food groups in a plate). Levels 4 and 8 contained a brief question. In Level 6, children were instructed to choose healthy food versus junk food. At last, Level 10 contained a bonus level. At Level 10, the player is provided with a free game related to adventure. This game can be started by enrolling the player's name. Player can choose a preferred male or female icon (Figure 2a). There is a brief instruction on how to play each level (Figure 2b). Each level can be completed by an optimum score (Figure 2c). The score is dependent on several questions. If the player gets a high score, he/she will get a card and can then unlock other levels. The cards contained nutrition and health materials (Figure 3a-b) that can be read before continuing to the next level. In this study, since the computers in both schools were limited, the children were divided into two sessions, with two to three students in a group at each session 


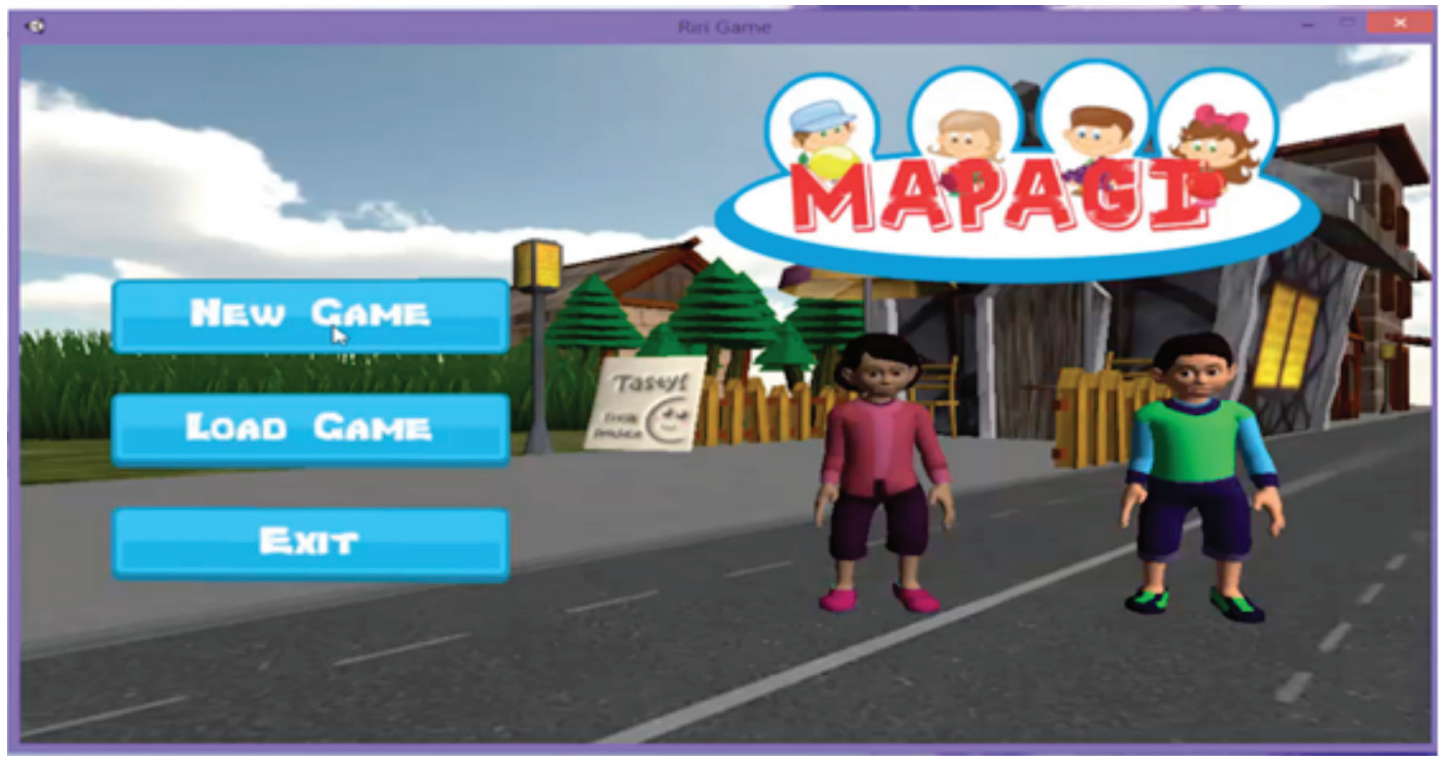

(a)

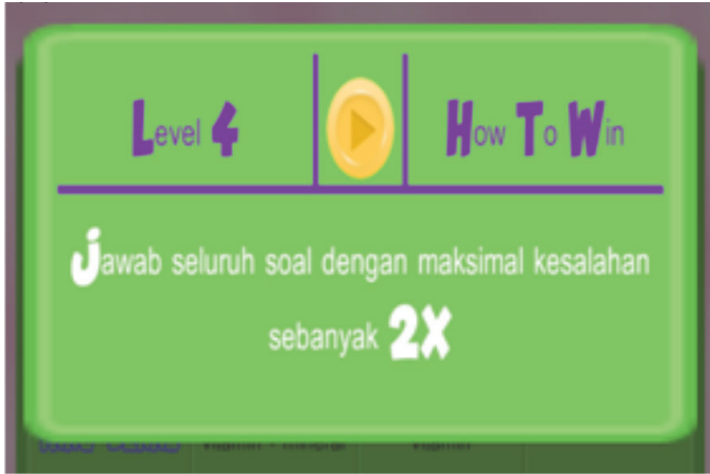

Food Quiz 4/5

(b)

(c)

Figure 2. (a) starting window; (b) window of Level 4 MAPAGI; (c) one of the Level 4 questions

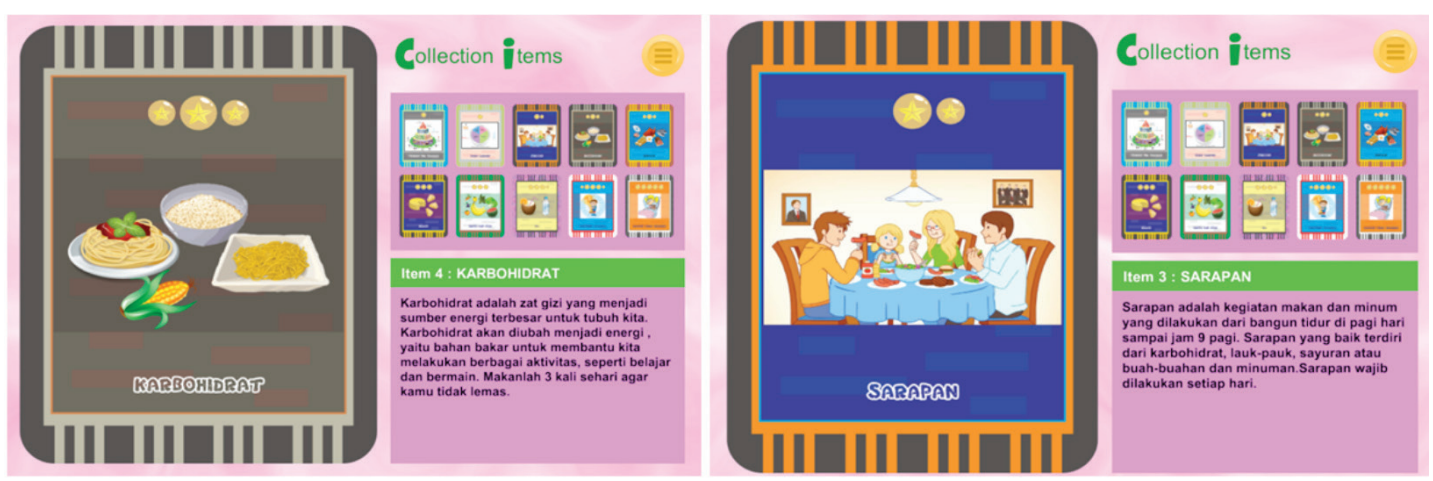

Figure 3. (a) View of card after completing Level 4; (b) View of card after completing Level 3 
Data presentation and statistical analyses

Parental and children characteristics were presented descriptively by $n(\%)$. Total knowledge score was produced from a cumulative of correct answers. For each question, a correct response was coded as 1 and an incorrect response as 0 hence maximum score was 25 . The responses for attitude questions were: strongly agree, agree, disagree, and strongly disagree, and they were coded as $4,3,2$, and 1 respectively. The maximum score for attitude questions was 80 .
Both knowledge and attitude scores were examined by paired and independent $t$-test. Paired $t$-test was used for examining within-group mean difference, while independent $t$-test was used for examining betweengroup (intervention versus control) mean difference. For continuous data, normality distribution was determined by the Kolmogorov-Smirnov test (normal if $p>0.05$ ). Descriptive statistics for continuous data were expressed as mean and standard deviation for normally distributed data, and median (IQR, interquartile range, 25th-75th

Table 1. Children and parental characteristics $(n=228)$

\begin{tabular}{|c|c|c|c|c|c|c|c|}
\hline \multirow{3}{*}{ Variables } & \multicolumn{6}{|c|}{ Groups } & \multirow[b]{3}{*}{ p-value } \\
\hline & \multicolumn{3}{|r|}{$I G$} & \multicolumn{3}{|r|}{$C G$} & \\
\hline & $n$ & $\%$ & $\begin{array}{c}\text { Median } \\
\text { (Q25th-Q75th) }\end{array}$ & $n$ & $\%$ & $\begin{array}{c}\text { Median } \\
\text { (Q25th-Q75th) }\end{array}$ & \\
\hline Children's age, year & & & $\begin{array}{c}10.00 \\
(10.0-11.0)\end{array}$ & & & $\begin{array}{c}10.00 \\
(9.0-10.0)\end{array}$ & $0.030^{*}$ \\
\hline 9 & 18 & 15.8 & & 30 & 26.3 & & \\
\hline 10 & 64 & 56.1 & & 62 & 54.4 & & \\
\hline 11 & 32 & 28.1 & & 22 & 19.3 & & \\
\hline \multicolumn{8}{|l|}{ Children's Sex } \\
\hline Male & 54 & 47.4 & & 53 & 40.0 & & 0.894 \\
\hline Female & 60 & 52.6 & & 61 & 60.0 & & \\
\hline \multicolumn{8}{|c|}{ Father's schooling years } \\
\hline$>12$ & 81 & 71.1 & & 87 & 76.3 & & 0.367 \\
\hline$\leq 12$ & 33 & 28.9 & & 27 & 23.7 & & \\
\hline \multicolumn{8}{|c|}{ Mother's schooling years } \\
\hline$>12$ & 70 & 61.4 & & 86 & 75.4 & & 0.023 \\
\hline$\leq 12$ & 44 & 38.6 & & 28 & 24.6 & & \\
\hline \multicolumn{8}{|c|}{ Father's working status } \\
\hline Not working & 3 & 2.6 & & 1 & 0.9 & & \\
\hline Private sector & 92 & 80.7 & & 91 & 79.8 & & 0.529 \\
\hline Public sector & 19 & 16.7 & & 22 & 19.3 & & \\
\hline \multicolumn{8}{|c|}{ Mother's working status } \\
\hline Not working & 47 & 41.2 & & 55 & 48.2 & & \\
\hline Private sector & 55 & 48.2 & & 45 & 39.5 & & 0.410 \\
\hline Public sector & 12 & 10.5 & & 14 & 12.3 & & \\
\hline
\end{tabular}

$\mathrm{IG}=$ intervention group; $\mathrm{CG}=$ control group

${ }^{\dagger}$ Chi-square test

*significant at $p<0.05$; Mann-Whitney U-test 
quartile) for not normally distributed data. Analysis of covariance (ANCOVA) test was performed to have adjusted differences between groups towards potential confounding variables. Confounding variables potentially came from variations in children age, parental characteristics such as education level and working status, hence MannWhitney U-test and Chi-square were used to determine these confounding factors.

\section{Ethical approval}

The current study obtained ethical approval from the Faculty of Health Sciences, Universitas Esa Unggul under the serial number 023/FIKES/X/2016. Permission was also obtained from the school headmaster, teacher and students' parents.

\section{RESULTS}

The characteristics of the school children and their parents are shown in Table 1 and are reported as $n(\%)$. The sample population's age ranged from 9-11 years old, with more than half of the children aged ten years old for both groups ( $\mathrm{IG}=56.1 \%$ vs. $\mathrm{CG}=54.4 \%$ ). Across the groups, the children's sex distribution was almost equal $(\mathrm{IG}=52.6 \%$ vs. $\mathrm{CG}=60 \%$ ), whereby female composed more than half of the samples. Most parents had completed 12 years of schooling, whereby fathers' schooling years were relatively higher than the mothers' across the groups. Related to working status, most fathers ( $\mathrm{IG}=96.4 \%$ vs. $\mathrm{CG}=99.1 \%$ ) were working and more than half of the mothers were working $(\mathrm{IG}=58.7 \%$ vs. $\mathrm{CG}=51.8 \%)$. Statistically, only the mother's schooling years was potentially a confounding variable $(p=0.023)$. However, since children's age and sex were mostly associated with their acceptance of educational materials, thus both variables were considered to be confounding variables.

Table 2 shows the children's knowledge and attitude scores on the importance of having breakfast before (pre-test/PT0), after 30 minutes (PT1) and 7 days after (PT2) the administration of nutrition education among intervention and control groups. Both groups were administered with printed and PowerPoint nutrition education materials, but only the intervention group was administered with the MAPAGI interactive video game. Except for pre-test (PTO IG vs. PTO CG), there was a significant difference in knowledge score between PT1 vs. PTO, PT2 vs. PT0 and PT2 vs. PT1 within each group. The mean difference between the mean changes of PT1 vs. PT0 (change 1), between the intervention group (4.82 \pm 2.53$)$ and control group $(1.75 \pm 2.66)$ was $3.08 \pm 0.34$ points and was statistically significant. The mean differences (standard deviation, SD) for change 2 and change 3 between both groups decreased to $2.00(0.34)$ and 1.07 (0.28), respectively. After adjustment for children's sex, age, and mother's education status, we found a significant difference in knowledge score between groups at all observed times. However, except for PT 1 and change 3, the mean difference of others decreased by about 0.4-0.9 points, but was still statistically significant. Related to the attitude score on the importance of having breakfast, except for change 3 , the mean difference of change $2(4.70 \pm 0.93)$ was greater than change $1(4.32 \pm 0.91)$ and both were statistically significant. Within each group, there were significant differences between PT1 vs. PTO and PT2 vs. PTO. However, the mean changes in attitude score for the intervention group (change $1=7.16 \pm 7.17$, change $2=7.34 \pm 7.11$ ) were almost three-fold to that of the 


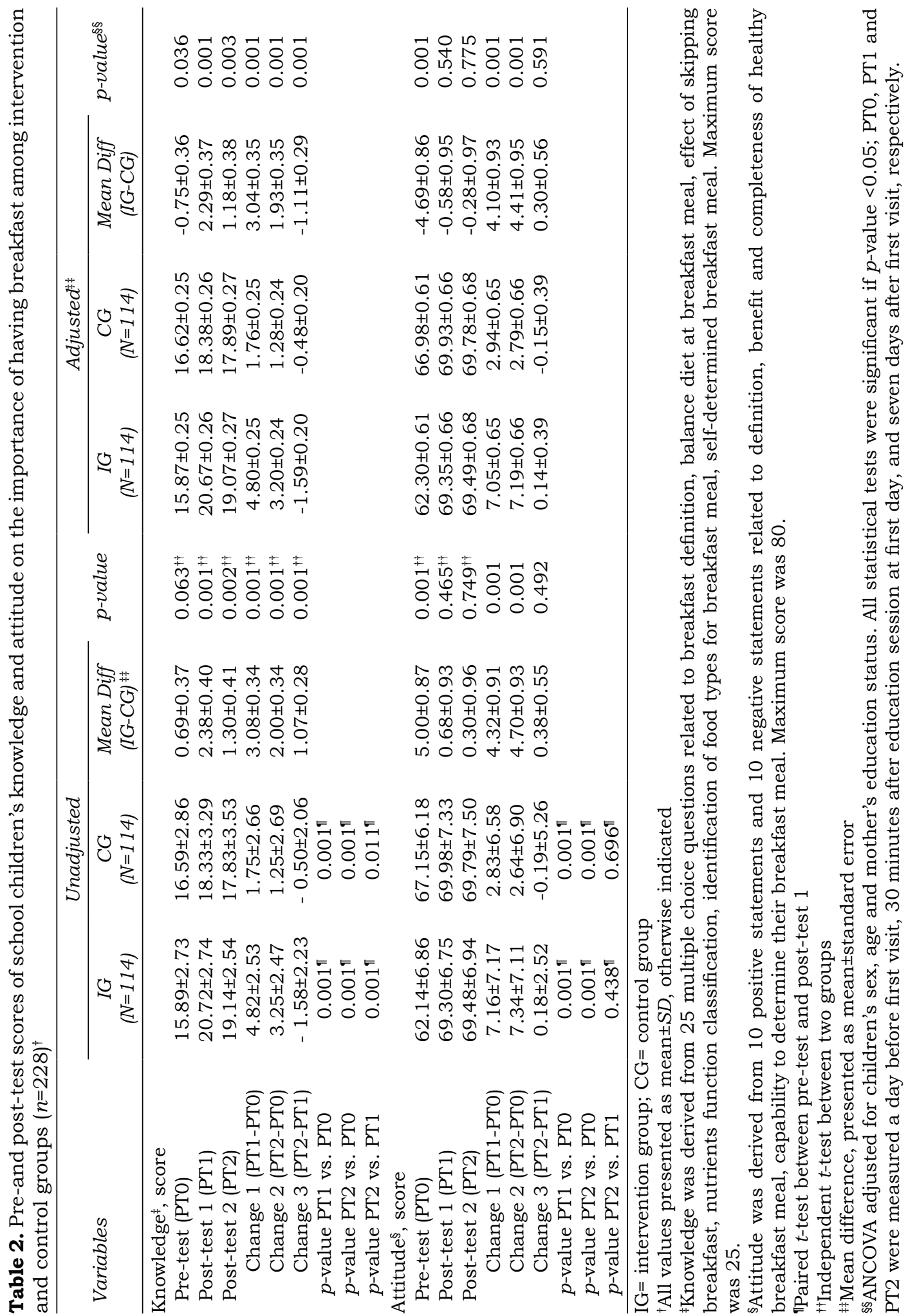


control group (change $1=2.83 \pm 6.58$, change $2=2.64 \pm 6.90)$. After adjustment for confounding variables, the mean differences (SD) for change 2 and change 1 decreased to $4.10(0.93)$ and $4.41(0.95)$ respectively, but both were statistically significant. No significant difference was observed for attitude score in change 3 between the intervention and control group.

\section{DISCUSSION}

In the present study, we found that the MAPAGI video game significantly improved school children's knowledge and attitude on the importance of having breakfast after adjustment for children's sex, age and mother's education status. This finding is in line with other studies such as Johnson-Glenberg, SavioRamos \& Henry (2014) who reported an increment in nutrition knowledge scores among 20 elementary school children in the United States after getting an "Alien Health" video game.

The effectiveness of video games in increasing the children's nutrition knowledge was also found by Schneider et al. (2012) in Messachusett-New England. They administered "Fitter Critters" towards 97 school-age children. Other studies in Indonesia found a significant increment in children's hygiene and sanitation after administration of a video game (Mawaddatin, 2015). These studies showed that video game can be a good alternative media for nutrition education to modify school-age children's eating habits. Parisod et al. (2014) and Ballesteros et al. (2017) emphasised that video games are an effective nutrition education tool for children to improve their knowledge and also give them good impact on their short and long-term memory. Most studies found that video game is an effective media to improve children's knowledge and attitude since children will learn about the concept easily, able to imagine, describe and even to test the concept (Angkasa et al., 2017).

However, in our study, it was observed that the mean differences in change (Change 1, Change 2, Change 3 ) of knowledge scores for both groups tended to reduce, while the change in the mean differences for children's attitude scores tended to increase. This is almost similar to Vardanjani et al. (2015) who found that the follow-up test scores of their sample population's knowledge and attitude were lower than pre-test for both groups (intervention vs. control). In the end, they concluded that the intervention was effective since performance about junk food among samples improved significantly compared with the control group. We assumed that the reduction in knowledge score was part of the internalisation process since attitude score increased. Kigaru et al. (2015) explained that knowledge alone is not sufficient to change the students' behaviours and there is a need for a positive attitude to be shaped properly.

In the current study, attitude did not change significantly over seven days of the first post-test (PT1). However, we found an overall change trend in the IG group, which showed a positive increment (7.05 to 7.19 ), while it was conversely shown in CG (2.94 to 2.79). Based on the Knowledge-AttitudeBehaviour (KAB) Model, change in attitude needs some period of time (Baranowski et al., 2003), so considering 'the overall change trend', we assumed children in the MAPAGI group had a better, durable and positive attitude compared with their counterparts.

MAPAGI video game can be considered as an effective nutrition education media because it promotes learning experience for children. This game was designed to have several levels 
for children to complete. Each level contained stratified-learning objectives that may trigger the student to remember, understand and evaluate (Bloom's Taxonomy) their breakfast knowledge and attitude. Apart from that, the video game is a media which is appropriate for the characteristics of current children where digital technology such as hand phones, tablets, and computers are involved in daily activities. Video game, as a nutrition education media/tool, has its function to simplify complex concepts, thus helping to achieve good learning process (Neiger et al., 2012).

Several mechanisms may apply in explaining the greater scores achieved in both knowledge and attitude for the MAPAGI game group compared to its counterpart. Firstly, the video game presented breakfast concept by involving several body senses such as audio (listening), visual (watching) and kinesthetic (interactive finger touch) compared to the control group which was only intervened with a printed leaflet. Studies confirmed that the more senses are involved during the learning process, the better the students can remember, understand and even evaluate the concept (Angkasa et al., 2017; Ballesteros et al., 2017; Parisod et al., 2014). Secondly, group discussion which occurred during the game enabled students to test his/her own knowledge and attitude towards others. This discussion enabled them to question and answer each other, thus resulted in a convincing conclusion towards the concept. Thirdly, repetition in playing the games increased children's memory and developed their imagination (Mawaddatin, 2015).

Amongst the strengths, the current study had taken into account demographic characteristics (children's sex and age, parent's education and working status) as suggested by Baranowski et al., (2003) and had provided two post-tests to explore the short and long term memory of school children's knowledge and attitude. A short coming of the current study is that the effects of the effects of the video game were not observed for a longer period as any improvement in eating behaviour and dietary pattern are expected to require a longer time of nutrition education.

\section{CONCLUSION}

MAPAGI video game is a good nutrition education tool to promote good knowledge and attitude on the importance of having breakfast among school children. However, we suggest future study to use longer observation time and include the observation of a change in dietary patterns of the children.

\section{Acknowledgment}

The authors would like to thank all teachers, parents and children who were involved in this research. Their solid cooperation made this research possible. The current study was funded by Universitas Esa Unggul and its publication has been also supported by the PT Anta Citra through Gizi dan Kesehatan Sekolah (GISEL) Program @ giselprogram.

\section{Authors' contribution}

DA, designed the study, prepared literature reviews and equipments, coordinated and supervised data collection and data cleaning, further analysed and interpreted the data, prepared the manuscript, supervised RAP in data collection and cleaning; RAP, designed the study, prepared literature reviews and equipments, coordinated data collection, further analysed and interpreted the data, and prepared the manuscript; IJ, designed the study, prepared literature reviews and equipments, coordinated and supervised data collection and data cleaning, further analysed and interpreted the data, and prepared the manuscript; gave valuable inputs on design and statistical analysis. All authors revised and approved the final manuscript before submission.

\section{Conflict of interest}

The authors declare that they have no competing interest. 


\section{References}

Adolphus K, Lawton CL \& Dye L (2013). The effects of breakfast on behavior and academic performance in children and adolescents. Front Hum Neurosci 7:425.

Angkasa D, Sitoayu L, Putri VR \& Mulyadi M (2017). Peduli Sarapan Dan Makanan Sehat, Serta Higiene Dan Sanitasi Lingungan Sekolah Pada Siswa Sekolah Dasar Di Kecamatan Sepatan Timur. Jurnal Pengabdian Masyarakat AbdiMas 3(2):19-27.

Ballesteros S, Mayas J, Ruiz-Marquez E, Prieto A, Toril P, de Leon LP, de Ceballos M \& Avilés JMR (2017). Effects of video game training on behavioral and electrophysiological measures of attention and memory: protocol for a randomized controlled trial. JMIR Res Protoc 6(1):e8.

Baranowski T, Cullen KW, Nicklas T, Thompson D \& Baranowski J (2003). Are current health behavioral change models helpful in guiding prevention of weight gain efforts? Obes Res $11(\mathrm{~S} 10): 23 \mathrm{~S}-43 \mathrm{~S}$.

Briawan D, Ekayanti I \& Koerniawati RD (2014). Pengaruh media kampanye sarapan sehat terhadap perubahan pengetahuan, sikap, dan kebiasaan sarapan anak sekolah dasar di Kabupaten Bogor. J Gizi Pangan 8(2):115-122.

CDC (2012). Parent engagement: Strategies for involving parents in school health. Centers for Disease Control and Prevention, Atlanta.

Eliassen EK (2011). The impact of teachers and families on young children's eating behaviours. Young Children 66(2):84-89.

Garg M, Rajesh V \& Kumar P (2014). Effect of breakfast skipping on nutritional status and school performance of 10-16 years old children of Udupi district. Health Popul Perspect Issues 37(3\&4):98-117.

Irnani H \& Sinaga T (2017). Pengaruh pendidikan gizi terhadap pengetahuan, praktik gizi seimbang dan status gizi pada anak Sekolah Dasar. J Gizi Indonesia (The Indonesian Journal of Nutrition 6(1):58-64.

Johnson-Glenberg MC, Savio-Ramos C \& Henry H (2014). "Alien Health": A nutrition instruction exergame using the kinect sensor. GAMES FOR HEALTH: Research, Development, and Clinical Applications 3(4):241-251.

Kawafha M (2013). Impact of skipping breakfast on various educational and overall academic achievements of primary schoolchildren in Northern of Jordan. Aust $J$ Basic Appl Sci 7(7):155-160.
Kigaru DMD, Loechl C, Moleah T, Macharia-Mutie CW \& Ndungu ZW (2015). Nutrition knowledge, attitude and practices among urban primary school children in Nairobi City, Kenya: a KAP study. BMC Nutrition 1(1):44.

Maduretno IS, Wirawan NN \& Setijowati N (2015). Niat dan perilaku pemilihan jajanan anak sekolah yang mendapat pendidikan gizi metode ceramah dan TGT. IJHN 2(1):23-37.

Mawaddatin PF (2015). Pengaruh imaginative pretend play dengan media video animasi: pengetahuan dan sikap perilaku hidup bersih dan sehat. THE SUN 2(1):38-46.

Neiger BL, Thackeray R, Van Wagenen SA, Hanson CL, West JH, Barnes MD \& Fagen MC (2012). Use of social media in health promotion: purposes, key performance indicators, and evaluation metrics. Health Promot Pract 13(2):159-164.

Nuryanto N, Pramono A, Puruhita N \& Muis SF (2014). Pengaruh pendidikan gizi terhadap pengetahuan dan sikap tentang gizi anak Sekolah Dasar. J Gizi Indonesia 3(1):32-36.

Parisod H, Pakarinen A, Kauhanen L, Aromaa M, Leppänen V, Liukkonen TN, Smed J \& Salanterä S (2014). Promoting children's health with digital games: A review of reviews. GAMES FOR HEALTH: Research, Development, and Clinical Applications 3(3):145-156.

Permaesih D \& Rosmalina Y (2017). Keragaman Bahan Makanan untuk Sarapan Anak Sekolah di Indonesia. Gizi Indonesia 39(1):25-36.

Pratiwi RA (2015). Pengaruh Penyuluhan Menggunakan Media Video Game Terhadap Pengetahuan, Sikap, Konsumsi Energi dan Protein Makan Pagi Pada Murid SDN 177 Dan SDN 187 Palembang (Karya Tulis Ilmiah). Poltekkes Kemenkes Palembang, Palembang.

Schneider KL, Ferrara J, Lance B, Karetas A, Druker S, Panza E, Olendzki B, Andersen V \& Pbert L (2012). Acceptability of an online health videogame to improve diet and physical activity in elementary school students: "Fitter Critters". GAMES FOR HEALTH: Research, Development, and Clinical Applications 1(4):262-268.

Shafiee G, Kelishadi R, Qorbani M, Motlagh ME, Taheri M, Ardalan G, Taslimi M, Poursafa, P, Heshmat R \& Larijani B (2013). Association of breakfast intake with cardiometabolic risk factors. Jornal de Pediatria 89(6):575-582. 
Silveira JA, Taddei JA, Guerra PH \& Nobre MR (2011). Effectiveness of school-based nutrition education interventions to prevent and reduce excessive weight gain in children and adolescents: a systematic review. Jornal de Pediatria 87(5):382-392.

Smith KJ, Blizzard L, McNaughton SA, Gall SL, Breslin MC, Wake M \& Venn AJ (2017). Skipping breakfast among 8-9 year old children is associated with teacher-reported but not objectively measured academic performance two years later. BMC Nutrition 3(1):86.
Vardanjani AE, Reisi M, Javadzade H, Pour ZG \& Tavassoli E (2015). The Effect of nutrition education on knowledge, attitude, and performance about junk food consumption among students of female primary schools. $J$ Edu Health Promot 4:53. doi: 10.4103/22779531.162349. 